\title{
Gorontalo
}

\section{Accounting Hournal}

Vol. 3 No. 2 October 2020

P-ISSN: 2614-2074, E-ISSN: 2614-2066

Nationally Accredited Journal, Decree No.36/E/KPT/2019

\section{THEORETICAL STUDY OF FINANCIAL REPORTING ON BUMDES REVIEWED FROM SAK ETAP KAJIAN TEORITIS PELAPORAN KEUANGAN PADA BUMDES DITINJAU DARI SAK ETAP}

\author{
Hasna Adilah, Utpala Rani \\ Program Studi Akuntansi Fakultas Ekonomi, Universitas Tidar \\ Jalan Kapten Suparman No.39, Tuguran, Potrobangsan, Magelang \\ Email : hasnaa3199@gmail.com
}

Submit : 2020-06-27; Revision : 2020-09-30; Publish : 2020-10-06 Gorontalo Accounting Journal, 3(2): 116-127

\begin{abstract}
The aim of this research is to theoretically assess the financial report making of BUMDes applied to the default of SAK ETAP. The research uses a qualitative research using descriptive approach. The result of the research shows that SAK ETAP is the suitable way as the guideline for BUMDes financial report, since it provides a simple and understandable report for the BUMDes financial report user. Financial report which presented using SAK ETAP's standard are: balance sheet, income statements, equity changes, cash flow report, and record of financial report (CALK).
\end{abstract}

Keywords: Financial statements; SAK ETAP

\begin{abstract}
ABSTRAK
Tujuan penelitian ini adalah mengkaji secara teoritis penyusunan laporan keuangan BUMDes jika diterapkan dengan Standar Akuntansi Keuangan untuk Entitas Tanpa Akuntabilitas Publik (SAK ETAP). Penelitian ini menggunakan jenis penelitian kualitatif dengan menggunakan pendekatan deskriptif. Hasil penelitian ini menunjukan bahwa SAK ETAP sangat cocok digunakan sebagai pedoman penyusunan laporan keuangan BUMDes, karena penyusunan laporan keuangan yang sederhana dan mudah dipahami oleh pengguna informasi laporan keuangan BUMDes. Laporan keuangan yang disajikan dengan standar SAK ETAP adalah : Neraca, Laporan Laba Rugi, Laporan Perubahan Ekuitas, Laporan Arus Kas, dan Catatan Atas Laporan Keuangan (CALK).
\end{abstract}

Kata Kunci: Laporan Keuangan; SAK ETAP

\section{PENDAHULUAN}

Seiring perkembangan zaman, Indonesia merupakan salah satu negara yang berkembang dalam sektor perekonomian. Dalam perkembangannya yang pesat maka dibutuhkan peran akuntansi sebagai alat untuk menghubungkan dan mengkonfirmasikan transaksi keuangan yang penting. Maka setiap perusahaan atau setiap organisasi harus menyusun laporan keuangan. 
Menurut Standar Akuntansi (IAI, 2009), laporan keuangan memiliki fungsi sebagai penyedia informasi yang berkaitan dengan posisi keuangan, kinerja, serta perubahan posisi keuangan sebuah perusahaan yang berguna bagi penggunannya (pengguana internal dan pengguan eksternal) dalam proses pengambilan keputusan. Menurut Lingtong, Limpeleh, dan Sungkowo (2020) Laporan keuangan merupakan bentuk pertanggung jawabankepada pihak internal maupun eksternal. Pihak internal yang dimaksud terbagi menjadi tiga yaitu : 1) manajemen, memerlukan laporan keuangan BUMDes untuk mengetahui keberhasilan suatu BUMDes yang dijalankan apakah sudah mencapai tujuan yang direncanakan. 2) pemegang saham atau investor, untuk melihat laba atau rugi pada suatu BUMDes dan untuk menentukan keputusan investasi pada BUMDes. 3) karyawan, karyawan membutuhkan laporan keuangan BUMDes bertujuan untuk mengetahui apakah BUMDes yang mempekerjakannya bisa membayar gajinya. Sedangkan pengguna informasi eksternal yaitu : 1) kreditur, membutuhkan informasi laporan keuangan BUMDes untuk mengetahui apakah BUMDes bisa mengembalikan pinajamna tepat waktu. 2) pemerintah, membutuhkan informasi laporan keuangan BUMDes untuk mengetahui pertanggung jawaban dana desa yang digunakan dan mengetahui kinerjanya.

Sejalan dengan perkembangan akuntansi di Indonesia setiap perusahaan harus membuat laporan keuangan yang dapat memberikan informasi kepada para pengguna yang beragam dan memiliki kebutuhan yang berbeda. Oleh karena itu penyusunan laporan keuangan diperlukan standar akuntansi. Saat ini ada 4 macam standar akuntansi yang diterbitkan oleh Dewan Standar Akuntansi Ikatan Akuntan Indonesia (DSAK IAI) dan 1 acuan standar yang dikeluarkan oleh Komite Standar Akuntansi Pemerintah (KSAP). Standar yang ditetapkan dan digunakan oleh banyak entitas swasta atau lembaga negara. Menurut IAI standar penyusunan laporan keuangan tersebut berupa Pernyataan Standar Akuntansi Keuangan (PSAK) dan pada tahun 2015 PSAK resmi mengadopsi Standar Pelaporan Keuangan Internasional (IFRS), Standar Akuntansi Keuangan untuk Entitas Tanpa Akuntabilitas Publik (SAK ETAP), Standar Akuntansi Syariah (SAS), Exposure Draft Standar Akuntabilitas Keuangan Mikro, Kecil, dan Menengah (ED SAK EMKM), Standar Akuntansi Pemerintah (SAP).

Permendes, (2019) tentang pedoman umum pembangunan dan Pemberdayaan Masyarakat Desa diterbitkan untuk melaksanakan pembangunan desa yang partisipatif dan berkesinambungan serta bersinergi untuk pembangunan pemberdayaan masyarakat desa dengan program pemerintah dan pemerintahan daerah, dan perlu menyusun pedoman tentang pembangunan dan pemberdayaan masyarakat desa. Pemberdayaan Masyarakat Desa merupakan sebuah lembaga pemerintahan daerah yang mengatur, mendampingi, dan menjalankan program- program yang bertujuan untuk kemandirian ekonomi desa dan yang sesuai dengan esensi masalah dan memprioritaskan kebutuhan Masyarakat Desa. Dalam pemerintahan Daerah bidang yang menangani tentang keswadayaan masyarakat adalah Dinas Pemberdayaan Masyarakat dan Desa (DISPERMADES). Dinas Pemberdayaan Masyarakat dan Desa sangat menyoroti adanya BUMDes atau Badan Milik Desa yang bertujuan meningkatkan kemampuan masyarakat dalam mengendalikan perekonomian di Desa untuk sebesar- besarnya kesejahteraan 
masyarakat dan kemandirian ekonomi tingkat desa. Pembangunan desa berbasiskan kekuatan lokal (keuangan dan aset desa) diwujudkan dalam pembentukan dan pengembangan produk unggulan kawasan pedesaan, digerakkan dan dikelola oleh desa melalui Badan Usaha Milik Desa (BUMDes) pada lingkup desa atau BUMDes bersama pada lingkup antar desa.

Kemenkeu, (2014) menyebutkan bahwa desa dapat mendirikan Badan Usaha Milik Desa yang disebut dengan BUMDes, BUMDes dikelola menggunakan asas semangat kekeluargaan dan gotong royong, BUMDes dapat menjalankan usaha dibidang ekonomi atau pelayanan umum sesuai dengan ketentuan peraturan perundang undangan, juga menjelaskan bahwa pendiriaan BUMDes disepakati melalui musyawarah Desa, dan pendiriaan BUMDes sebagaimana yang diatur dengan ayat 1 ditetapkan dengan peraturan desa. Sifat dari BUMDes menjadi alat desa bagi gerakan perekonomian di Desa yang bercirikan semangat kolektif dan gotong royong, dengan maksud untuk melaksanakan tugas desa dengan menyelenggarakan cabang - cabang produksi yang penting bagi desa dan yang menguasai hajat hidup orang banyak. Indikator terlaksananya penerapan prinsip akuntansi pada BUMDes yaitu dengan adanya penyelenggaraan akuntansi yang tepat. BUMDes merupakan lembaga yang bergerak dalam bidang perekonomian desa yang memiliki identitas dan dasar hukum maka penerapan dan penyusunan laporan keuangan pada BUMDes harus berpedoman dan sesuai dengan standar akuntansi sehingga informasi dan kualitas laporan keuangan bersifat akuran, andal, dan relevan untuk pengguna informasi laporan keuangan. (Kemendes, 2019) Peraturan Menteri Desa, pembangunan daerah tertinggal, dan transmigrasi Republik Indonesia Nomor 4 Tahun 2019 tentang pendirian, pengurusan dan pengelolaan, dan perubahan pada BUMDes pada bab 111 pasal 12 ayat 3 menyatakan bahwa pelaksanaan operasional atau seorang manajer dan direktur berwenang membuat laporan keuangan seluruh unit usaha BUMDes setiap bulan.

Salah satu pentingnya menentukan pedoman atau standar akuntansi yang digunakan untuk menyusun laporan keuangan BUMDes adalah informasi atas laporan keuangan adalah menyusunan yang lengkap dan dapat bermanfaat bagi pengguna laporan keuangan tersebut. Artinya dalam hal ini penyusunan laporan standar akuntansi harus sesuai dengan Standar Akuntansi Keuangan Entitas Tanpa Akuntabilitas (SAK ETAP). Dalam SAK ETAP penyajian laporan keuangannya lengkap yang terdiri dari : Neraca, Laporan Laba Rugi, Laporan Perubahan Ekuitas, Laporan Arus Kas, dan Catatan atas Laporan Keuangan. Dalam hal ini maka BUMDes harus menyusun laporan keuangan secara lengkap sesuai dengan pedoman SAK ETAP.

Penelitian ini berfokus kepada penyusunan laporan BUMDes dengan pedoman Standar Akuntansi Keuangan dengan Entitas tanpa Akuntabilitas Publik pada Dinas Pemberdayaan Masyarakat dan Desa Kabupaten Magelang karena dilatarbelakangi dengan belum ada standar yang digunakan untuk menyusun laporan keuangan pada BUMDes. Pada pelaporan keuangan BUMDes yang ada di Dispermades Kabupaten Magelang masih menggunakan laporan keuangan sederhana. Alasan dilakukan penelitian ini karena laporan yang dibuat BUMDes belum memiliki laporan keuangan yang lengkap, laporan yang dibuat berupa laporan kas masuk dan kas keluar, hal ini tidak 
menggambarkan posisi keuangan periode dan tidak diketahui keuantungan atau kerugian suatu BUMDes. padahal pedoman Mentri Keuangan harus menggunakan laporan laba/rugi, laporan perubahan modal, laporan neraca, laporan arus kas. Pada penelitian terdahulu Rudiantoro dan Veronika (2012) yang berjudul "kualitas laporan keuangan UMKM serta prospek implementasi SAK ETAP" menyimpulkan bahwa latar belakang pendidikan tidak terbukti signifikan terhadap kualitas laporan keuangan UMKM menyebabkan kualitas laporan keuangan tidak berpengaruh positif terhadap besarnya jumlah kredit yang diterima. SAK ETAP menjadi harapan untuk dapat meningkatkan kualitas laporan keuangan menjadi lebih baik. Penelitian ini bertujuan untuk mengkaji secara teoritis pelaporan pada penyusunan laporan keuangan BUMDes jika ditinjau atau diterapkan dengan menggunakan Standar Akuntansi Keuangan Entitas Tanpa Akuntabilitas Publik (SAK ETAP).

\section{METODE PENELITIAN}

Penelitian ini menggunakan jenis penelitian kualitatif dengan menggunakan pendekatan deskriptif. Menurut Sugiyono, (2010) adalah cara ilmiah untuk mendapatkan data dengan tujuan dan kegunaan tertentu dengan ciri- ciri keilmuan, yaitu rasional, empiris, dan sistematis. Peneliti dapat memilih jenis- jenis metode dalam pelaksanaan penelitiannya. Penelitian yang bermaksud untuk memahami fenomena tentang apa yang dialami oleh subyek penelitian. Penelitian ini menggunakan tipe penelitian deskriptif yaitu penelitian yang bertujuan untuk mendeskripsikan secara terperinci mengenai fenomenafenomena sosial tertentu yang berkenaan dengan masalah dan untuk diteliti.

Teknik pengumpulan data pada penelitian ini menggunakan kajian literatur terhadap SAK ETAP yang sesuai dengan penyusunan laporan keuangan BUMDes. Kajian literatur merupakan jembatan bagi peneliti untuk mendapatkan landasan teoritis yang meliputi mencari, membaca, dan menelaah laporan penelitian dan bahan pustaka yang memuat teori yang relevan dengan penelitian yang akan dilakukan.

Teknik pengumpulan data yang kedua adalah wawancara bersama Ibu Norma selaku Kasubag pemberdayaan Masyarakat di Dinas Pemberdayaan Masyarakat Kabupaten Magelang. Peneliti menanyakan tentang perkembangan BUMDes di Kabupaten Magelang, macam - macam laporan keuangan BUMDes, Standar Akuntansi yang digunakan untuk membuat laporan keuangan BUMDes, pengguna informasi keuangan BUMDes internal maupun eksternal.

Teknik pengumpulan data yang selanjutnya adalah observasi. Penulis melibatkan diri langsung dan mengamati masuknya laporan keuangan BUMDes yang sudah dibuat dari BUMDes di desa- desa Kabupaten Magelang.

\section{HASIL DAN PEMBAHASAN}

Dinas Pemberdayaan Masyarakat dan Desa Kabupaten Magelang merupakan lembaga yang diberi tanggung jawab untuk pengelolaan, pembangunan, dan perkembangan untuk kemajuan perekonomian desa. Maka dibentuklah Badan Usaha Milik Desa atau disebut dengan BUMDes sebagai program prioritas utama pada DISPERMADES. BUMDesa beroperasi pada bidang sektor prioritas ekonomi suatu desa yang membawa keuntungan. BUMDes tentu saja menginginkan suatu usaha yang ditekuni menjadi berkembang, untuk mengembangkan suatu usahanya BUMDes perlu 
meyakinkan kepada masyarakat jika usaha yang ditekuninya bisa dipertanggungjawabkan (Kemenkeu, 2017).

Dari hasil wawancara bersama Ibu Norma selaku Kasubag Pemberdayaan Masyrakat terkait dengan penerapan standar akuntansinya, Dinas Pemberdayaan Masyarakat dan Desa kabupaten Magelang belum menerapkan standar Akuntansi Keuangan pada laporan keuangan BUMDes di Kabupaten Magelang, dan pelaporannnya masih menggunakan laporan keuangan yang sederhana. Laporan keuangan sederhana yang dibuat yaitu laporan kas harian yang merupakan kas masuk dan kas keluar sehingga tidak menggambarkan neraca untuk mengetahui keuntungan atau kerugian BUMDes. Dari hasil observasi atau pengamatan laporan Laporan Pertanggung jawaban kepada pihak eksternal pemerintahan Kabupaten Magelang, laporannya yang dibuat sangat sederhana sehingga pihak pemerintah kurang memahami gambaran kinerja secara nyata.

Menurut kementrian keuangan cara BUMDes mempertanggung jawabkan usahanya dengan menyusun sebuah laporan keuangan. laporan keuangan merupakan hasil dari proses akuntansi selama usaha tersebut beroperasi, laporan keuangan juga menghasilkan informasi yang bermanfaat untuk pengguna informasi. Dalam penyusunan informasi maka dibutuhkan suatu standar akuntansi yang digunakan sebagai pedoman penyusunan laporan keuangan. Penyusunan keuangan BUMDes di desa belum menetapkan standar yang digunakan sebagai pedoman laporan keuangan BUMDes . Menurut Arinanda pada judul "Rekonstruksi penyusunan laporan keuangan unit usaha susu Ndosari berdasarkan SAK ETAP pada BUMDes Makmur Abadi berbasis microsoft exel menyimpulkan dari hasil penelitiannya bahwa unit usaha susu Ndosari masih belum menerapkan laporan keuangan yang belum sesuai dengan SAK ETAP, oleh karena itu penelitiannya mencoba untuk menyusun laporan keuangan yang sesuai dengan SAK ETAP. Supaya dapat dijadikan pedoman untuk menyusunan laporan keuangan yang lebih akuntabel. Maka pemerintah Dinas Pemberdayaan Masyarakat dan Desa Kabupaten Magelang perlu menetapkan standar akuntansi untuk menyusun laporan keuangan, yaitu dengan standar SAK ETAP.

Menurut Martani, (2011) Karakteristik SAK ETAP sebagai berikut :

1. Stand alone accounting standar ( tidak mengacu kepada SAK umum ) yang artinya merupakan standar yang berdiri sendiri secara keseluruhan.

2. Mayoritas menggunakan historical cost concept

3. Mengatur transaksi yang umum dilakukan Usaha Kecil, Menengah, dan tidak memiliki akuntabilitas publik

4. Pengaturan lebih sederhana dibandingkan SAK Umum

a) Alternatif yang dipilih adalah alternatif sederhana

b) Penyederhanaan pengakuan dan pengukuran

c) Pengurang pengungkapan

5. Tidak boleh berubah selama beberapa tahun.

Menurut IAI (2016), Laporan Keuangan SAK ETAP yaitu : 
1. Neraca

Neraca merupakan laporan keuangan perusahaan yang memberikan informasi posisi keuangan perusahaan pada akhir periode. Pos- pos dalam neraca yaitu : kas dan setara kas, piutang usaha dan piutang lainnya, persediaan, properti investasi, aset tetap, aset tidak berwujud, utang usaha dan utang lainnya, aset dan kewajiban pajak, kewajiban diestimasi, dan ekuitas.

Tabel 1. Contoh Neraca BUMDes dengan SAK ETAP

\begin{tabular}{|c|c|c|c|}
\hline Aset & & & \\
\hline Aset L & & & \\
\hline $1-111$ & Kas Kecil BUMDes & Rp. & $\mathrm{xxx}$ \\
\hline $1-112$ & Kas di Bank Daerah & & $\mathrm{xxx}$ \\
\hline $1-113$ & Piutang Usaha & & $\mathrm{xxx}$ \\
\hline $1-114$ & Persediaan Barang Dagangan & & $\mathrm{xxx}$ \\
\hline & Total Aset Lancar & & $\mathrm{xxx}$ \\
\hline Aset T & & & \\
\hline $1-211$ & Kandang Ayam & Rp. & $\mathrm{xxx}$ \\
\hline $1-212$ & Akumulasi Penyusutan Kandang & & $\mathrm{xxx}$ \\
\hline & Total Aset Tetap & & $\mathrm{xxx}$ \\
\hline & TOTAL ASET & & $\mathrm{xxxx}$ \\
\hline Hutan & & & \\
\hline $2-110$ & Hutang Dagang & Rp. & $\mathrm{xxx}$ \\
\hline $2-130$ & Hutang Gaji & & $\mathrm{xxx}$ \\
\hline & Total Hutang & & $\mathrm{xxx}$ \\
\hline Modal & & & \\
\hline $3-120$ & Modal Pemerintah Desa & Rp. & $\mathrm{xxx}$ \\
\hline $3-130$ & Iktisar Laba Rugi & & $\mathrm{xxx}$ \\
\hline & Total Modal & & $\mathrm{xxx}$ \\
\hline & Total hutang + modal & & $\mathrm{xxxx}$ \\
\hline
\end{tabular}

Sumber : IAI, Laporan Keuangan SAK ETAP, (2016).

2. Laporan Laba Rugi

Laporan laba rugi menyajikan hubungan antara penghasilan dan beban dari entitas. Laba digunakan sebagai patokan untuk tingkat kinerja karyawan atau perhitungan pengembalian investasi. Unsur- unsur laporan keuangan secara tidak langsung yang terkait dengan pengukuran laba adalah penghasilan dan beban. Laporan laba rugi mencangkup pospos sebagai berikut : pendapatan, beban keuangan, bagian laba rugi atau rugi dari investasi yang menggunakan metode ekuitas, beban pajak, laba atau rugi neto. 
Tabel 2. Contoh laporan laba rugi BUMDes dengan SAK ETAP

\begin{tabular}{|c|c|c|c|}
\hline \multicolumn{4}{|c|}{ PENDAPATAN } \\
\hline $4-110$ & Pendapatan bunga bank & \multirow[t]{4}{*}{$\mathrm{Rp}$} & $\mathrm{xxx}$ \\
\hline $4-120$ & Pendapatan penjualan barang & & $\mathrm{xxx}$ \\
\hline $4-130$ & $\begin{array}{l}\text { Pendapatan penjualan telur } \\
\text { ayam }\end{array}$ & & $\mathrm{xxx}$ \\
\hline $4-150$ & $\begin{array}{l}\text { Pendapatan pompa angin } \\
\text { Total pendapatan }\end{array}$ & & $\begin{array}{l}\mathrm{xxx} \\
\mathrm{xxx}\end{array}$ \\
\hline \multicolumn{4}{|c|}{ BEBAN-BEBAN } \\
\hline $6-110$ & Beban Gaji & \multirow[t]{7}{*}{$\mathrm{Rp}$} & $\mathrm{xxx}$ \\
\hline $6-140$ & Beban Konsumsi & & $\mathrm{xxx}$ \\
\hline $6-160$ & Beban Foto Copy & & $\mathrm{xxx}$ \\
\hline $6-150$ & Beban Rapat & & $\mathrm{xxx}$ \\
\hline $6-170$ & $\begin{array}{l}\text { Beban Penyusutan } \\
\text { Total beban }\end{array}$ & & $\begin{array}{c}\mathrm{xxx} \\
(\mathrm{xxx})\end{array}$ \\
\hline $\begin{array}{l}\text { Laba u } \\
\text { Beban }\end{array}$ & ebelum pajak & & $\begin{array}{l}\mathrm{xxxx} \\
(\mathrm{xxx})\end{array}$ \\
\hline Laba u & etelah pajak & & $\mathrm{xxxx}$ \\
\hline
\end{tabular}

Sumber : IAI, Laporan Keuangan SAK ETAP, (2016).

3. Laporan perubahan ekuitas

Dalam laporan perubahan ekuitas suatu periode, termasuk didalamnya pos pendapatan dan beban diakui secara langsung dalam ekuitas untuk periode tersebut, pengaruh perubahan kebijakan akuntansi dan koreksi kesalahan yang diakui dalam periode tersebut. Perubahan ekuitas selain perubahan yang timbul dari transaksi dengan pemilik dalam kapasitasnya sebagai pemilik ekuitas selama suatu periode.

Tabel 3. Contoh laporan perubahan ekuitas BUMDes dengan SAK ETAP

\begin{tabular}{|c|c|c|}
\hline & & $20 X 1$ \\
\hline Modal Awal & $\mathrm{Rp}$. & $\mathrm{xx}$ \\
\hline \multicolumn{3}{|l|}{ Ditambah : } \\
\hline 1. Laba tahun berjalan & & $\mathrm{xxx}$ \\
\hline Total Penambahan & & $\mathrm{xxx}$ \\
\hline Dikurangi : & & $(\mathrm{xxx})$ \\
\hline Modal Akhir & & $\operatorname{xxxx}$ \\
\hline
\end{tabular}

Sumber : IAI, Laporan Keuangan SAK ETAP, (2016).

4. Laporan Arus Kas

Laporan arus kas merupakan laporan yang menyajikan tentang arus kas masuk dan arus kas keluar dalam suatu perusahaan. Laporan arus kas biasanya terdapat perhitungan arus kas aktivitas investasi, kas aktivitas operasi, dan kas aktivitas pendanaan. 
Tabel 4. Contoh laporan Arus Kas BUMDes dengan SAK ETAP

\begin{tabular}{|c|c|c|c|}
\hline Arus Kas Aktivitas Operasi & & & $20 X 1$ \\
\hline Mutasi LK & Keterangan & & Saldo \\
\hline 1-Jan & $\begin{array}{l}\text { Pendapatan bunga } \\
\text { bank }\end{array}$ & $\mathrm{Rp}$ & $\mathrm{xxx}$ \\
\hline 2-Jan & $\begin{array}{l}\text { Pendapatan } \\
\text { penjualan barang } \\
\text { dagangan }\end{array}$ & & $\mathrm{xxx}$ \\
\hline 3-Jan & $\begin{array}{l}\text { Pendapatan } \\
\text { penjualan telur ayam }\end{array}$ & & $\mathrm{xxx}$ \\
\hline 4-Jan & $\begin{array}{l}\text { Pendapatan pompa } \\
\text { angin }\end{array}$ & & $\mathrm{xxx}$ \\
\hline 5-Jan & Beban Gaji & & $\mathrm{xxx}$ \\
\hline 6-Jan & Beban Konsumsi & & $\mathrm{xxx}$ \\
\hline 7-Jan & Beban Foto Copy & & $\mathrm{xxx}$ \\
\hline 8-Jan & Beban Rapat & & $\mathrm{xxx}$ \\
\hline 9-Jan & $\begin{array}{l}\text { Beban Penyusutan } \\
\text { Arus kas dari } \\
\text { aktivitas operasi }\end{array}$ & & $\begin{array}{l}\mathrm{xxx} \\
\mathrm{xxx}\end{array}$ \\
\hline $\begin{array}{l}\text { Arus Kas Aktivitas Investasi } \\
1-F e b \\
\text { Arus Kas Aktivitas Pendanaan }\end{array}$ & Pembelian Peralatan & & $\mathrm{xxx}$ \\
\hline 1-Mar & $\begin{array}{l}\text { Modal } \\
\text { Kenaikan Bersih Kas } \\
\text { Saldo Kas per } 1 \\
\text { Desember }\end{array}$ & & $\begin{array}{l}x x x \\
x x x \\
x x x\end{array}$ \\
\hline Saldo kas per 31 desember & & & $\mathrm{xxxx}$ \\
\hline
\end{tabular}

Sumber : IAI, Laporan Keuangan SAK ETAP, (2016).

5. Catatan atas Laporan Keuangan

Catatan atas laporan keuangan berisi tentang informasi yang disajikan dalam laporan keuangan. catatan atas laporan keuangan memberikan penjelasan atas transaksi atau pos - pos dan akun pada setiap laporan keuangan yang disusun oleh suatu perusahaan.

Tabel 5. Contoh CALK BUMDes dengan SAK ETAP

1 UMUM

Badan Usaha Milik Desa "Kineauan" Desa Wawona berlokasi di Jaga

IV Kecamatan Tatapaan Kab. Minahasa Selatan. BUMDes Kineauan didirikan sejak tahun 2017, dengan bidang usaha : perdagangan umum (berupa penjualan kebutuhan pertanian dan spareparts kendaraan roda dua), serta pemeliharaan ayam petelur 
2 Ikhtisar Kebijakan Akuntansi

a.

b.

c.

d.
Pernyataan Kepatuhan

Laporan keuangan disusun berdasarkan SAK ETAP

Dasar Penyusunan

Penyusunan laporan keuangan menggunakan akrul basis Aset Tetap Aset tetap disusutkan menggunakan metode garis lurus

Pengakuan Pendapatan dan Beban

Pendapatan diakui pada saat penerimaan dari pelanggan dan beban diakui pada saat terjadinya transaksi.

\begin{tabular}{cl}
\hline 3 & Kas \\
\hline & Kas berjumlah Rp. Xxx \\
\hline 4 & Piutang Usaha \\
\hline \multicolumn{2}{l}{ Piutang Usaha berjumlah Rp. Xxx } \\
Sumber : IAI, Laporan Keuangan SAK ETAP, (2016).
\end{tabular}

Selanjutntya berikut ini penerapatan SAK ETAP menurut IAI :

Tabel 6. Penerapan SAK ETAP menurut Ikatan Akuntansi Indonesia (IAI)

\section{PERKIRAAN} keuangan

Aset tetap dan

Properti Investasi

Aset tidak berwujud

\section{Instrumen}

keuangan

Persediaan

Penurunan Nilai

Aset

\section{SAK ETAP}

Minimum pos yang harus ada di neraca lebih sedikit. Silent terhadap pos luar biasa, laporan laba rugi (tanpa harus menyajikan laba rugi komprehensif), cash flow dengan metode tidak langsung.

Aset tetap, roperti investasi menggunakan metode biaya kecuali ada ketentuan pemerintah yang mengharuskan model revaluasi diterapkan.

Aset tidak berwujud diamortisasikan selama 10 tahun. Pengukuran menggunakan metode biaya.

Ruang lingkup, investasi pada efek tertentu klarisikasi trending, held to maturity dan evailable for sale. Lah tersebut mengacu pada PSAK no 50 (1998).

Tidak di ijinkan menggunakan persediaan dengan pendekatan LIFO. Ruang lingkup yang meliputi semua jenis aset kecuali aset yang timbul dari manfaat pensiun. Tidak mengatur penurunan nilai goodwill dan ada tambahan pinjaman yang diberikan PSAK 31 . 


\begin{tabular}{|c|c|}
\hline $\begin{array}{l}\text { Laporan Keuangan } \\
\text { Konsolidasi }\end{array}$ & $\begin{array}{l}\text { Tidak diatur bila memiliki investasi atas asosiasi } \\
\text { maupun subsidiary menggunakan metode } \\
\text { ekuaitas }\end{array}$ \\
\hline Sewa & $\begin{array}{l}\text { Tidak mengatur perjanjian yang mengandung } \\
\text { sewa (PSAK 8) - klarifikasi sewa kombinasi IFRS } \\
\text { for SMEs dan SFAS } 13 \text { ( rue based ) - laporan } \\
\text { keuangan lessee dan lessor menggunakan PSAK } \\
30 \text { (1990) akuntansi sewa. }\end{array}$ \\
\hline Biaya pinjaman & Biaya pinjaman langsung dibebankan \\
\hline Imbalan kerja & $\begin{array}{l}\text { Dalam SAK ETAP imbalan tidak termasuk dalam } \\
\text { motode ekuitas terapi bisa menggunakan motode } \\
\text { sederhana. }\end{array}$ \\
\hline Pajak penghasilan & $\begin{array}{l}\text { Menggunakan tax payable concept. Tidak ada } \\
\text { pengakuan dan pengukuran pajak tangguhan. }\end{array}$ \\
\hline
\end{tabular}

Sumber : IAI, Implementasi SAK ETAP, (2019).

Penerapan SAK ETAP pada laporan keuangan BUMDes sangat diperlukan, alasannya bahwa laporan keuangan yang menggunakan standar akuntansi SAK ETAP mempunyai kelengkapan dalam penyusunan laporan keuangan. Informasi mengenai keuangan sangat dibutuhkan khususnya untuk manajemen yang digunakan untuk pengambilan keputusan, kita juga dapat melihat posisi keuangan suatu organisasi pada BUMDes (Rudini, 2016). Undang-undang No.6 Tahun 2014 tentang Desa didalamnya membahas pembentukan BUMDes namun dalam pelaksanaan penetapan kebijakan, pelaksanaan, dan pengelolaan BUMDes masih banyak permasalahan dengan aspek manajemen, standar akuntansinya. Maka pemerintah menetapkan SAK ETAP sebagai standar pedoman dalam penyusunan laporan keuangan BUMDes, karena laporan keuangan akan menjadi lebih fleksibel, lengkap, dan mudah dipahami oleh pengguna informasi laporan keuangan BUMDes.

Menurut IAI, (2016) manfaat menggunakan SAK ETAP pada laporan keuangan yaitu: 1) entitas yang dimaksud dapat menyusun laporan keuangan sendiri. 2) laporan keuangan yang dibuat menggunakan standar akuntansi SAK ETAP dapat diaudit sebagai evaluasi kinerja BUMDes dan mendapatkan opini audit tentang kewajaran penyusunan laporan keuangan. 3) laporan keuangan yang disusun menggunakan SAK ETAP dapat menghasilkan informasi dan digunakan untuk menghasilkan peminjaman dana sebagai pengembangan usahanya.

Menurut pendapat dari Narsa, (2012) penggunaan SAK ETAP sangat diperlukan untuk menyusun laporan keuangan BUMDes karena kelengkapan laporan keuangan yang lengkap sehingga bisa memberikan informasi yang akurat terhadap pengguna laporan keuangan. dibandingkan dengan SAK UMKM mempunyai banyak kendala yang dihadapi selain modal, sistem pembukuannya sangat sederhana dan cenderung mengabaikan kaidah administrasi keuangan yang standar (baku). Padahal laporan keuangan yang akurat dan baku akan banyak membantu dalam pengembangan bisnisnya secara kuantitatif dan kualitatif. Hal ini menunjukan bahwa SAK ETAP memberikan solusi untuk penyusunan laporan keuangan yang lengkap, serta sederhana, dan mudah dipahami. Hanya mengatur transaksi yang dilakukan usaha kecil dan menengah. Serta alternatif yang digunakan dalam SAK ETAP 
sangat sederhana karena di dalam penyusunan laporan keuangan SAK ETAP pengakuan dan penilaiannya dilakukan penyederhanaan. Jika suatu usaha atau perusahaan yang menetapkan SAK ETAP dalam periode berikutnya tidak boleh berganti standar selama beberapa tahun.

\section{PENUTUP}

Dari penelitian ini dapat disimpulkan bahwa Dinas Pemberdayaan masyarakat Desa Kabupaten Magelang belum menerapkan Standar Akuntansi untuk BUMDes di Kabupaten Magelang sehingga laporan keuangan yang digunakan sebagai bentuk tanggung jawab hanya berupak kas harian yaitu kas masuk dan kas keluar. Sehingga para investor tidak tahu kerugian atau keuntungan atas kepemilikan aset dalam suatu BUMDes tersebut.

SAK ETAP sangat cocok digunakan sebagai pedoman penyusunan laporan keuangan keungan BUMDes karena standar ini sangat sederhana dibanding standar lainnya dan tidak menyulitkan saat penyusunan. Dalam SAK ETAP ada beberapa laporan keuangan yang harus disusun BUMDes yaitu Neraca, Laporan perubahan ekuitas, laporan Arus Kas, Laporan Laba-Rugi, dan Catatan Atas Laporan Keuangan (CALK). Laporan keuangan BUMDes tidak hanya digunakan untuk lembaga komersial tetapi juga lembaga sosial, sehingga dibutuhkan laporan atas kegiatan-kegiatan yang diadakan oleh BUMDes.

\section{DAFTAR PUSTAKA}

Arinanda, P. ( 2019 ). Rekontruksi Penyusunan Laporan Keuangan Unit Usaha Susu Ndosari Berdasarkan SAK ETAP pada BUMDes Makmur Abadi berbasis Microsoft Exel.

Harahap. (2010). Analisis Kritis Atas Laporan Keuangan . Jakarta : PT Raja Grafindo Persada .

I Made Narsa, A. W. (2012). Mengungkapkan Kesiapan UMKM dalam Implementasi Standar Akuntansi Keuangan Entitas Tanpa Akuntanbilitas Publik (PSAK-ETAP) Untuk Meningkatkan Akses Modal Perbankan. Majalah Ekonomi Tahun XXII, No. 3 Desember 2012.

IAI. (2016). Laporan Keuangan SAK ETAP. Diambil kembali dari iaiglobal: http: / /iaiglobal.or.id/v03/standar-akuntansi-keuangan/etap

IAI. (2019, November Selasa, Rabu). Implementasi SAK ETAP . Diambil kembali dari iaiglobal: http://iaiglobal.or.id/v03/PPL/email_ppl794.html\#: :text=Implementasi\%20SAK\%20ETAP,menggunakan\%20PSAK \%20umum\%20yang\%20berlaku.

Jerry Sonny Lintong, Esrie A.N. Limpeleh, dan Barno Sungkowo. (2020). Laporan Keuangan Berdasarkan SAK ETAP pada BUMDes "Kineauan" Desa Wawono Kabupaten Minahasa Selatan . JBK Jurnal Bisnis \& Kewirausahaan .

Kemendes. (2019). Peraturan Menteri Desa, Pembangunan Daerah Tertinggal, Dan Transmigrasi Republik Indonesia NO 17 Tentang Pedoman Umum Pembangunan Dan Pemberdayaan Masyarakat Desa.

Kemenkeu. (2014). Undang-Undang No 6 Tahun 2014 Pasal 88 tentang pendirian BUMDes yang disepakati melalui musyawarah desa. Diambil kembali dari jdih.kemenkeu.go.id:

https://jdih.kemenkeu.go.id/fulltext/2014/6TAHUN2014UU.htm 
Kemenkeu. (2014). Undang-Undang No6 . Diambil kembali dari jdih.kemenkeu.go.id: https://jdih.kemenkeu.go.id/fulltext/2014/6TAHUN2014UU.htm

Kemenkeu. (2017). Buku Saku Dana Desa, Dana Desa Untuk Kesejahteraan Rakyat: Menciptakan Lapangan Kerja, Mengatasi Kesenjangan, dan Mengentaskan Kemiskinan. Jakarta: Direktorat Jenderal Perimbangan Keuangan.

Keuangan, K. (2017). Undang- Undang No.6 Tahun 2014 pasal 88 ayat 1 Pendirian BUMDes Melalui peraturan Desa . Jakarta : Direktorat Jendral Perimbangan Keuangan.

Martani, D. (2011, Maret 15). Standar Akuntansi Keunagan Entitas Tanpa Akuntanbilitas Publik (SAK - ETAP) . Diambil kembali dari staff.blog.ui.ac.id: https://staff.blog.ui.ac.id/martani/files/2011/03/Standar-AkuntansiKeuanan-Entitas-Tanpa-Akuntanbilitas-Publik-SAK-ETAP.pdf

Martani, D. (2012). Akuntansi Keuangan Menengah Berbasis PSAK. Jakarta: Salemba Empat .

Munawir. (2010). Analisis laporan Keuangan . Yogyakarta: Liberty.

Permendes. (2019). Permendes PDTT No 17 Tahun 2019 . Diambil kembali dari dpmd.bengkaliskab.go.id:

http: / /www.dpmd.bengkaliskab.go.id/publikasi/149-permendes-pdtt-no17-tahun-2019-tentang-pedoman-umum-pembangunan-danpemberdayaan

PSAK. (2015, Juni). PSAK 1 Penyajian Laporan Keuangan. Diambil kembali dari http: / /www.iaiglobal.or.id/:

http://www.iaiglobal.or.id/v03/files/file_publikasi/ED\%20PSAK\%201\%2 0(26\%20Juni\%202015).pdf

Rudini. (2016). Analisis Penerapan SAK ETAP Pada Badan Usaha Milik Desa (BUMDES) Langkitin di Desa Langkitin. E-journal Mahasiswa Prodi Akuntansi VOL 2, NO 1.

Rudini. (2016). Analisis Penerapan SAK ETAP Pada Badan Usaha Milik Desa (BUMDES) Langkitan di Desa Langkitin. E-Journal Mahasiswa Akuntansi VOL 2, NO 1 .

Sugiyono. (2010). Metode Penelitian Pendidikan Pendekatan Kuantitatif, kualitatif,. Bandung: Alfabeta.

Undang-undang Republik Indonesia Nomor 6 Tahun 2014 tentang pembentukan BUMDes Lembarang Negara Republik Indonesia tahun 2014, Jakarta. 